Muséologies

Les cahiers d'études supérieures

muséologies

\title{
The Many Faces of Knowledge Production in Art Museums: An Exploration of Exhibition Strategies
}

\section{Emilie Sitzia}

Volume 8, numéro 2, 2016

Les nouveaux paradigmes

URI : https://id.erudit.org/iderudit/1050765ar

DOI : https://doi.org/10.7202/1050765ar

Aller au sommaire du numéro

Éditeur(s)

Association Québécoise de Promotion des Recherches Étudiantes en

Muséologie (AQPREM)

ISSN

1718-5181 (imprimé)

1929-7815 (numérique)

Découvrir la revue

Citer cet article

Sitzia, E. (2016). The Many Faces of Knowledge Production in Art Museums: An Exploration of Exhibition Strategies. Muséologies, 8(2), 141-156.

https://doi.org/10.7202/1050765ar

Tous droits réservés (C Association Québécoise de Promotion des Recherches Étudiantes en Muséologie (AQPREM), 2018
Ce document est protégé par la loi sur le droit d'auteur. L'utilisation des services d'Érudit (y compris la reproduction) est assujettie à sa politique d'utilisation que vous pouvez consulter en ligne.

https://apropos.erudit.org/fr/usagers/politique-dutilisation/ 
Article cinq

The Many Faces of Knowledge Production in Art Museums:

An Exploration of Exhibition Strategies

Emilie Sitzia 
Dr. Emilie Sitzia is an associate professor in the department of literature and art at Maastricht University and the director of the Master Arts and Heritage programme. She teaches cultural education, curatorship and interdisciplinary research methods, as well as 19 th and 20th-century art and literature. She publishes regularly on art, literature and museum studies topics. 


\section{Introduction}

Art museums have fluid and changing identities, ranging from elite galleries that display the dominant culture, to spaces that feature exhibitions investigating personal psychological or emotional issues. Many emphasize displays of power, while other museums position themselves as tools for the democratisation of knowledge ${ }^{1}$. Eilean Hooper-Greenhill emphasises that museums' operational modes and identities shift "according to the context, the plays of power, and the social, economic, and political imperatives that surround them" ${ }^{2}$. However, in recent decades, knowledge production has become a central aim for museums ${ }^{3}$. This is in part due to the developments of new forms of visitor-centred mediation such as new museology, constructivist museum approaches, or participatory practices ${ }^{4}$. Museums now define their mission in terms of knowledge production ${ }^{5}$ and as Hooper-Greenhill emphasises: "knowledge is now well understood as the commodity that

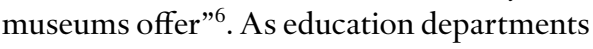
in art museums throughout the world are gradually renamed 'services to the public' or 'interpretation department', and as museums see themselves as "centers for public learning" ${ }^{7}$, one must ask, what precisely is meant by knowledge production in art museums?

\subsection{Knowledge production in art museum: definitions}

Niels Gottschalk-Mazouz defines knowledge as a cluster concept with seven characteristics:

- knowledge has a practical aspect;

- knowledge is person-bound or not (personalised or represented knowledge co-exist and are dependent);

- knowledge has a normative structure;

- knowledge is internally networked (linked to existing internal knowledge);

- knowledge is externally networked;

- knowledge is dynamic;

- and knowledge has institutional contexts ${ }^{8}$.
1 Linda Nochlin in 1972 highlighted that museums contain an inherent contradiction as they serve as both a temple of the arts for the elite and an instrument for democratic education. This is still an issue today, especially for art museums. NOCHLIN, Linda. "Museums and radicals". In O'DOHERTY, Brian (ed.). Museums in Crisis. New York: G. Braziller, 1972, p. 8.

2 HOOPER-GREENHILL, Eilean. Museums and the Shaping of Knowledge. London: Routledge, 1992, p. 1.

3 HEIN, George. Learning in the Museum. London: Routledge, 1998, p. 3.

4 For considerations on new museology see, for example: VERGO, Peter. The New Museology. London: Reaktion Books, 1989; DAVALLON, Jean. L'exposition à l'œuvre: stratégies de communication et médiation symbolique. Paris: L'Harmattan, 1999; SANDELL, Richard. "Museum as Agent of Social Inclusion". Museum Management and Curatorship. vol. 17, $\mathrm{n}^{\circ}$ 4, 1998, p. 401-418; MAIRESSE, François and André DESVALLÉES. Vers une redéfinition du musée. Paris: L'Harmattan, 2007; MAIRESSE, François. Le Musée, temple spectaculaire: une histoire du projet muséal. Lyon: Presses de l'Université de Lyon, 2002; MARSTINE, Janet. New Museum Theory and Practice: An Introduction. Oxford: Blackwell, 2006. For considerations on constructivist museums see, for example: DEWEY, John. Democracy and education. Champaign: Project Guttenberg. <https://www.gutenberg. org/files/852/852-h/852-h.htm\#link2HCH0008> (retrieved in May 2016); HEIN, George. "The Constructivist museum". In. HOOPER-GREENHILL, Eilean. The educational role of the Museum. London: Routledge, 1999; FALK, John and Lynn DIERKING. Learning from Museums: Visitor experiences and the making of meaning. Walnut Creek: AltaMira Press, 2000. For considerations on participatory practices see: SIMON, Nina. The Participatory Museum. Santa Cruz: Museum 2.0, 2010. McSWEENEY, Kayte and Jen KAVANAGH (ed.). Museum participation: New directions for audience participation. Edinburgh: Museums Etc, 2016; SHIRKY, Clay. Here Comes Everybody: The power of organizing without organizations. New York: Penguin Press, 2008.

5 HEIN, George. "Museum Education". In. MACDONALD, Sharon. A Companion to Museum Studies. Oxford: Blackwell Publishing, 2006, p. 340.

6 HOOPER-GREENHILL, op. cit., p. 2.

7 FALK, John and Lynn DIERKING. The Museum Experience Revisited. Walnut Creek, CA: Left Coast Press, 2013, p. 14.

8 GOTTSCHALK-MAZOUZ, Niels. "Internet and the flow of knowledge: Which ethical and political challenges will we face?". In. Wittgenstein and the Philosophy of Information. Frankfurt: Ontos Verlag, 2008. p. 218-222. 
More generally, knowledge production has gradually expanded beyond factual, normative information. The defining element of our current knowledge societies is "not the centrality of knowledge and information, but the application of such knowledge and information to knowledge generation and information processing/communication devices, in a cumulative feedback loop between innovation and

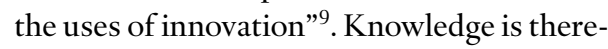
fore now considered not only as cognitive or emotional information as many theoreticians of education state ${ }^{10}$, but also as the skills with which to produce more knowledge on the basis of existing knowledge ${ }^{11}$.

As mentioned the issue this article looks to investigate is: what does knowledge production mean within the context of an art museum and can certain exhibition strategies promote a certain type of knowledge production? Artworks can be seen as "material traces of bodies of knowledge" ${ }^{12}$. The art object held in the museum is then central for the development of knowledge: it concentrates information on the artist and the artwork itself, but also the society that surrounded its production. But we can also consider the overall experience of the museum as an opportunity for knowledge production. Indeed, Kolb defines learning as "the

9 CASTELLS, Manuel. The Rise of Network Society. Malden: Blackwell Publishers, 1996, p. 32.

10 It is worth noting here that a dichotomy exists between theory and normative practices of education. Theories of education tend to acknowledge cognitive and emotional learning as equally valuable and as desirable outcomes of cultural education. However, in practice, the focus on clearly measurable factual information is broadly seen as the purpose of learning in museums. This is, in part, due to the modeling of the evaluation of museum knowledge production on the evaluation of education in formal environment that focus on cognitive output.

11 For more on the interaction between emotion and cognitive learning and the associated debate see: ZAJONC, Robert. "Feeling and Thinking: Preferences Need No Interferences”. American Psychologist. vol. 35, 1980, p. 151-175; ZAJONC, Robert. "On the Primacy of Affect". American Psychologist. vol. 39, 1984, p. 117-123; ILLERIS, Knud (ed.). Contemporary Theories of Learning. New York: Routledge, 2009; LAZARUS, Richard. "A Cognitivist's Reply to Zajonc on Emotion and Cognition". American Psychologist. vol. 36, 1981, p. 222-223; LAZARUS, Richard. "Thoughts on the Relations Between Emotion and Cognition”. American process whereby knowledge is created through the transformation of experience" ${ }^{13}$. The encounter with the object and the knowledge emanating from the object is then only a small part of the knowledge transfer and production that happens in the museum ${ }^{14}$. This is particularly true if we consider 'learning' in a broad manner and 'knowledge' as more than factual information. John Falk and Lynn Dierking distinguish between three types of learning potentially taking place in the museum: learning cognitive information, learning affective information, and learning psychomotor information ${ }^{15}$. But as we have seen, knowledge creation goes beyond information. It extends to the application of knowledge and its impact on the individual and on others. It also extends to the creation of normative structures, as well as the creation of internal and external networks. Knowledge creation is defined by its self-generating dynamism. The hypothesis this article puts forward is that knowledge production in the art museum has many faces and that some specific exhibition strategies promote a specific type of knowledge production. Knowledge production is a process that implies that on top of the acquisition of information, there will also be the development of diverse individual cognitive skills (such as analytical skills, critical skills, internal, external networking skills,

Psychologist. vol. 37, 1982, p. 1019-1024; LAZARUS, Richard. "On the Primacy of Cognition". American Psychologist. vol. 39, 1984, p. 124-129.

12 BUTTERS, Suzanne. "From Skills to Wisdom: Making, Knowing, and the Arts”. In. SMITH, Pamela, Amy MEYERS and Harold COOK. The Material Culture of Empirical Knowledge. Ann Harbour: The University of Michigan Press, 2014, p. 72.

13 KOLB, David. Experiential learning: Experience as the source of learning and development. Englewood Cliffs: Prentice-Hall, 1984, p. 38.

14 For more on museum and social learning see:

WENGER, Etienne. Communities of Practice: Learning, Meaning and Identity. Cambridge: Cambridge University Press, 1998; Id., "A Social Theory of Learning”. In. ILLERIS, op. cit.; WENGER-TRAYNER, Etienne, Omid OMIDVAR, and Roman KISLOV. "The Evolution of the Communities of Practice Approach: Toward Knowledgeability in a Landscape of Practice-An Interview With Etienne Wenger-Trayner". Journal of Management Inquiry. vol. 23, 2014. 15 FALK, John and Lynn DIERKING. The Museum Experience. Washington: Whalesback Books, 1992. 
etc.), diverse individual emotional skills (such as empathy, expanded imagination, creativity, etc.), a wide variety of individual psychomotor skills (how to look at a painting, move in a limited space, manipulate an artwork, etc.), as well as a range of social skills (normative museum behaviour or communication skills for example). Therefore, knowledge production in the art museum goes well beyond cognitive engagement and information transfer, and extends into emotional and psychomotor learning and skills development.

\subsection{Meaning making and knowledge production}

There is a significant difference between knowledge production and meaning making that is often not made explicit. Meaning making and knowledge production are related. Meaning making can be a form of knowledge production by creating new hypotheses on the interpretation of an artwork or meaning making can be the actualisation of knowledge such as applying expert knowledge to a specific object for example. But knowledge production and meaning making are not equivalents. Knowledge production is broader than meaning making because meaning making is mostly object-centred while knowledge production tends to be people-centred. It is here a matter of emphasis rather than opposition. The meaning-making process starts with the object and is intrinsically linked to the object. However, the knowledge produced in the museum may or may not be relevant to the object exhibited (normative behaviour in a museum might be an example of knowledge created that is not object related). But the knowledge created in the museum will be closely related to people: the museum staff, exhibition makers, and/or the audience. The challenge is even greater in the context of an art museum where the object's meaning is particularly variable and prone to change. As Ferguson argues, in art exhibitions, the idea that meanings are impossibly unstable is embraceable because inevitable. With works of art, meanings are only produced in context and that is a collective, negotiated, debated and shifting consensual process of determination. Representation is always in crisis, which is always a form of freedom ${ }^{16}$.

So it is important, when talking about knowledge production in the art museum to explicitely consider not only object-centred knowledge production but also people-centred knowledge and skills (understood as applied knowledge that potentially generates new knowledge).

\subsection{Autonomous artwork and knowledge production}

Another challenge for knowledge production in art museums is the perceived tension between an autonomous artwork (detached from life and having an independent set of values) and knowledge production (which is anchored in the cultural, social and physical environment it is produced in). However, it is worth noting that an artwork doesn't exist without social recognition (that is without being acknowledged as an artwork by the critics or institutions for example) and the presence of an audience. And as Mieke Bal highlights, as soon as an object is exhibited, and if we conceive exhibitions as an act of communication, the object can no longer be considered autonomous ${ }^{17}$. Furthermore, knowledge production is often perceived as inhibiting aesthetic experience in the museum. Bal underscores that the interference created by the museum as an institution and the interference produced by the social context in which the artwork is presented are "part and parcel of the experience of art" ${ }^{18}$. Knowledge production in the art museum is a direct consequence of these interferences.
16 FERGUSON, Bruce, Reesa GREENBERG and Sandy NAIRNE. Thinking About Exhibitions. London: Routledge, 1996, p. 186.
17 BAL, Mieke, "Exposing the Public". In. MACDONALD, op. cit., p. 529.

18 Ibid., p. 525 


\subsection{Hein as an explorative tool/ methodology}

To explore the kind of knowledge production happening in art museums this article will use George Hein's theory presented in his seminal book Learning in the Museum ${ }^{19}$. In this text, Hein offers a theoretical framework that is particularly useful when thinking about the position of art museums in regards to knowledge production. Hein's theory, which is familiar to many museum professionals, covers a range of forms of knowledge of production. This framework also facilitates the grouping of different types of knowledge production with specific exhibition strategies.

First Hein shows that there are two extreme positions taken by museums when it comes to theories of knowledge. In museums, knowledge can be considered as existing independently of the learner and as being linked to the 'real world' (realism). At the other extreme, knowledge can be considered as located and constructed in the mind of the learner (idealism) ${ }^{20}$. Key questions for the museums (answered tacitly or openly) are therefore,

Does the museum take the view that its mission is to impart truth, independently of the particular previous experiences, culture, and disposition of its visitors? Does the museum take the position that knowledge is relative, influenced by culture and needs to be explained and interpreted, depending on the purpose, use and situation ${ }^{21}$ ?

He continues by outlining two opposing museum positions when it comes to theories of learning. At one end, he places the transmission-absorption model where learners, seen as vessels to be filled, incrementally absorb pieces of knowledge. On the other end, he places learning theories that state that the learner constructs knowledge ${ }^{22}$.

Hein concludes with an outline of the different models, combining these four theoretical positions:

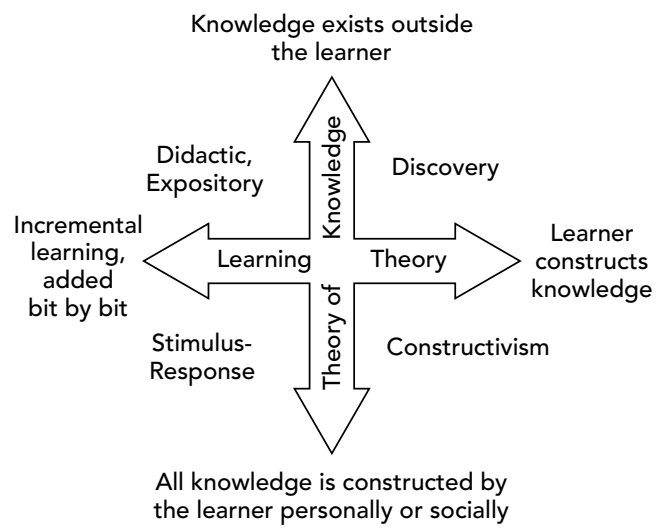

Figure 1

Hein's Model of Educational Theories ${ }^{23}$

These four models-didactic/expository, discovery, stimulus-response, and constructivism - will form the core theoretical framework of our analysis and drive the structure of the article as we ask ourselves what knowledge production looks like in art museums and what kind of knowledge is created ${ }^{24}$. Is knowledge production in art museums about creating new interpretations, experiencing the medium, creating new links, creating an emotional, empathic, or aesthetic knowledge, recognizing patterns, acquiring art historical facts, or develop analytical and critical skills? We will also ask who are the knowledge producers in each of the museum models: the artists, the curators, the education team, or the public? Finally we will ask how knowledge

24 The aim of this article is therefore not to offer a history of knowledge production in museums. It is also not the aim of this article to create an inventory of approaches to knowledge production in the field of arts and culture nor is it to explore the issues of social impact or power relations on knowledge production in museums.
19 HEIN, 1998, op. cit.

20 Ibid., p. 16-21.

21 Ibid., p. 19.

22 Ibid., p. 21-23.

23 Ibid., p. 25. 
production is shown in art museums and how specific exhibition strategies direct the type of knowledge created ${ }^{25}$. Each model from Hein's framework-didactic/expository, discovery, stimulus-response, and constructivism-will be contextualised for the art museums (that is museums that focus on the exhibition of fine arts), with a specific example to clarify our analysis. This article uses explanatory cases $^{26}$. The cases were selected for their representativeness of the practices in museum. For all cases the main source was exhibition documentation completed, when possible, with direct observation. Once this exploration of the diversity of knowledge production associated with specific exhibition strategies is carried out we will assess the possibility to go beyond Hein's standard models and explore what knowledge production would look like in alternative and hybrid models.

\section{Didactic/expository model: museums show and tell/visitors watch and learn}

The didactic/expository model adopts the position that knowledge exists independently from the learner and that learning is an incremental transfer of knowledge from the institution to the learner. Museums adopting this format focus on the objects rather than the visitor and on a sequential step-by-step approach. Hein identifies typical characteristics that such museums have: ordered sequential exhibition design (a clear beginning and end), didactic components such as labels or panels describing the learning content, a hierarchical organisation from simple to complex, and school-like educational structures (with clear learning goals and a didactic progression $)^{27}$.

\subsection{Art history as a driving discipline behind the didactic/expository exhibition strategy}

In the art museum the didactic/expository model is mostly found in art historically organised museums. Such institutions use art history as the main discipline grounding their reflection, organisation, display and interpretation of the collection. For example, in Paris (France), the Centre Pompidou's 'Présentation des collections modernes - 1905-1965' offers a chronological approach from modern to contemporary art. This case was chosen, as it is representative of a common strategy of exhibition in art museums, especially in larger institutions that are strongly connected to art history as a discipline and possess a large collection that allows them to display such a chronology. The case was analysed based on documentation and completed by a direct observation of the display.

The presentation of the permanent collection was redesigned in 2015 to focus on the readability of modern art history ${ }^{28}$. The museum adopted a "chronological format featuring major historical milestones, introducing visitors to key figures, works and movements making up the history of modern art, together with the 'go-betweens' who helped to construct the history of modernity" 29 . This linear art historical approach to art exhibitions is often found in large national collections that focus on reinforcing national art historical narrative or on placing this narrative in an international context.
25 We will focus here on the exhibition space itself and its content, not on extra material or associated educational programme. Such programme and educational material are often designed by a different team than the curatorial team (for example educational departments that may have very different ideas on the knowledge produced by the exhibition) Furthermore, what interest us here is knowledge production supported by artworks within exhibition space and how artworks function as catalysts for such production.
26 YIN, Robert. Case study research: design and methods. Thousand Oaks: Sage, 2003.

27 Ibid., p. 27-29.

28 Centre Pompidou. Interview of Centre Pompidou director Bernard Blistène. <https://www.centrepompidou.fr/cpv/ resource/cRLGzpp/ryX7Abx> (retrieved in June 2016). 29 Ibid. 


\subsection{Knowledge production in the didactic/expository model}

In this model the knowledge producer is traditionally the museum (curators, art historians, and educators). The kind of knowledge produced by visitors is linked to the recognition of specific patterns, and developments of internal and external networks. If we ask what form of knowledge is produced by visitors in such environments we can see that the focus is then on cognitive normative information and on recognition skills (internal and external networking). Factual information about the artwork, the artist, the art movement, its social and artistic context is at the core of the knowledge production apparatus created by the museum. Labels or other tools (audio-guides, podcasts, etc.) all aim to transfer information to the visitor (mostly cognitive and sometime emotional information). In this model, the knowledge produced by the visitors mostly stays invisible and the display of knowledge production is meant as a tool for disseminating the art historical discourse rather than stimu-

\section{lating on-going dynamic visitor knowledge} production.

\subsection{Issues related to knowledge production in the didactic/expository model: visibility of visitor's knowledge production and transparency}

In the didactic/expository model, public knowledge is created to reinforce an existing normative discourse. It is mostly an internal process and therefore stays predominantly invisible. Some museums try to make this knowledge creation process observable by adopting more open exhibitory practices such as participatory practices. While museums that employ participatory practices are trying to involve the public in knowledge production and attempt to make this knowledge visible to the rest of the public, these practices remain

30 Rijksmuseum. Birdwatching Rijksmuseum. <https://www. rijksmuseum.nl/en/vogelen> (retrieved in May 2016).

31 Accurate Art Annotations. 'http://annotate.accurator.nl/ intro.html' (retrieved in June 2016).

32 On the topic of expertise and online museum participatory practices see SCOTT, Eleanor. The Citizen Connoisseur:

'Art Detective' and the New Understandings of Expertise for relatively limited and stay within specific boundaries. For example, the Birdwatching Rijksmuseum day (Amsterdam, Netherlands) looked to use the skills of the public to identify species of birds in the Rijksmuseum's painting collection ${ }^{30}$. "Birdwatchers and avian enthusiasts" were invited to explore the digital collection, identify birds, and enter data in Wikimedia commons. This project is linked with 'Accurator'31, a platform that allows the public to tag digitised images from the art collection of the Rijksmuseum to improve the descriptions and searchability of the online collection. 'Accurator', while using public knowledge production potential also has some level of expertise built in the system to insure accuracy of descriptions. Moreover, it contains only three domains of expertise to which the public can contribute: birds, fashion and the Bible. So while it acknowledges the potential for public knowledge production, it insures control of interpretation by experts and limits the field of knowledge the public can contribute to. The knowledge produced by the visitors is about pattern recognition and creation of internal/external networks and production of factual information checked by experts. It stays very much in the didactic/expository mode of approach as the authority of the expert is not challenged and the authorship of knowledge is institutionalised. The usability and value given to that knowledge by the general public is also an issue as the main beneficiary of such an activity is the museum as an institution as well as specialist researchers ${ }^{32}$.

Beyond the invisibility of the public's knowledge production, the main issue for knowledge production in the didactic/expository exhibition model is the lack of transparency. As argued by Jane Deeth, the museum needs to expose its methods to be credible ${ }^{33}$. The institution needs to help the public understand

Arts and Heritage Practice. M.A thesis (Arts and Heritage), Maastricht University, 2016.

33 DEETH, Jane. "Engaging Strangeness in the Art Museum: An audience development strategy”. Museum \& Society. vol. 10, $\mathrm{n}^{\circ}$ 1, 2012, p. 11. 
the value of the expert in this knowledge-transfer process by, as Bal notes, "foreground[ing] rather than obscure[ing] the mechanisms and decisions that underlie the presentation of objects by means of an artificial coherence that is both provisional and indispensible" ${ }^{34}$. Exposing such mechanism would not necessarily threaten the didactic/expository model (as it would not inherently threaten the authority of the institution). However, in the traditional and participatory examples of the didactic/expository model presented here, this foregrounding of method is absent as the institutions focus on content rather than process.

\section{Stimulus-response model: museums show and prompt/visitors feel, do, and learn}

The stimulus-response model also emphasizes that knowledge is incrementally added bit by bit to the learner but "makes no claims for the objective truth of what is learned" ${ }^{35}$. Museums with this approach will be characterised, according to Hein, by didactic components outlining what is to be learned, by a sequential approach and by reinforcing components (that repeat and reward appropriate responses) ${ }^{36}$. As the focus here is not anymore on an art historical discourse (that would equate for art to 'the objective truth') but rather on diverse personal interpretations of the object, this model can be fruitful for art museums. The fluid interpretation of artworks and varied emotional and creative responses of the viewer become central in such a model.

\subsection{Engagement and creativity as key concepts behind the stimulus-response exhibition strategy}

The aim of the institution in such format is to stimulate a variety of interpretations and increase visitor's engagement and creativity.

34 BAL, op.cit., p. 526.

35 HEIN, 1998, op. cit., p. 29

36 Ibid., p. 29.

37 CLARKSON, Austin and Douglas WORTS. "The Animated Muse: An Interpretive Program for Creative Viewing”. Curator: The Museum Journal. vol. 8, n 3, 2005, p. 257-280. The authors themselves do not identify the
Interestingly, this model detaches itself from a normative art historical discourse, and focuses instead on the disciplines of psychology and fine arts education. An example of such an endeavour is the experiment by Austin Clarkson and Douglas Worts in the Art Gallery of Ontario in $1993^{37}$. This case was chosen as a representative case for art museums trying to encourage constructed meaning and extended engagement with the artwork within a stimulus-response model. The case was analysed through documentation. In order to increase engagement with the artwork (meaning both intensifying emotional engagement and increasing the time spent by the visitor with the artwork) and to expand the visitor's creative responses to the artworks (interpretation and meaning making), they proposed an 'exercise for exploring' the painting. This exercise consisted of a 12-minutes audio programme in a booth dedicated to a single painting. The audio programme promoted observation skills through prompts such as asking the viewer to scan the image slowly and then close their eyes and recompose it in their head. It also activated the imagination of the viewer and encouraged them to engage with the work through questions about temperature, sound and texture in the painting. It also stimulated further examination of the image by inviting the visitor to choose a spot in the painting and imagine exploring the landscape from that new vintage point. Finally, the exercise closed with a 'verification' phase documenting and promoting reflection on the experience with the help of specifically designed 'Share your reactions' response cards. In these cards visitors were invited to record their experience in words and/or images ${ }^{38}$. The visitor throughout this experiment was stimulated to produce diverse levels of interpretation of the work, and to create her/his own response (emotional and

experiment as a stimulus-reponse approach even though they are clearly looking to engage visitors and stimulate creative responses in the visitors. The experiment was successful as the "positive responses outnumbered the negative by more than 10 to one" p. 265.

38 Ibid., p. 263-264. 
intellectual) to the artwork. The forms of knowledge produced here are quite different from the didactic/expository model. The focus is on creating internal and external networks and the activity is deeply person-bound.

Emotional knowledge is created at an individual level (imagination, creativity, and personal identity development) and at a social level (empathy and communication of emotion in particular). Here the knowledge producers are partly the museum team that designed the activity - they produced the frame for the kind of knowledge created - and partly the public that shares the knowledge produced through the response cards.

\subsection{Issues related to knowledge production in the stimulus-response model: threat to curatorial authority and lack of visibility of the knowledge produced}

The issues in this model are twofold. Firstly, this type of exercise can be (and has been) perceived as a "threat to curatorial authority" 39 . When the interpretation is left to the visitor, it is perceived as a loss of knowledge from the viewpoint of the experts in the institution. However, the kind of questions asked in the programme focused on perception as well as creative and emotional reception rather than factual information. Rather than looking for an objective truth about the artwork, such an exhibition strategy is exploring the interpretative potential of the work. Furthermore, this programme was accompanied by two other audio tracks including a more traditional curatorial introduction and a presentation of the artist by friends and relatives. This insured that the process stayed in line with the institutional discourse. The process of image analysis also followed theories of both education and psychology applied to the fine arts. The analytical skills gained were then anchored in a clear disciplinary tradition.

39 Ibid., p. 262.

40 HEIN, 1998, op. cit., p. 31.

41 This issue of externally predetermined outcomes is highlighted by Hein. Ibid., p. 30-33.

42 Ibid., p. 33.
The other main issue is the very small number of visitors actually using the response cards (2\%). This left a large part of the knowledge produced invisible to the institution and the rest of the public.

\section{Discovery Model: museums show and ask/visitors think and learn}

With the discovery model, the focus shifts to the visitor/learner. The visitor constructs knowledge and learns how to learn as she/he goes along. Hein defines this model as "any form of education that attributes active participation on the learner" ${ }^{40}$, but still with specific educational outcomes ${ }^{41}$. Active learning is often characterised by 'hands-on' learning, by a form that allows exploration (not necessarily linear), as well as by a range of active learning activities, by didactic components in the form of questions, by means to compare the learner's interpretation with others (or 'correct ones'), and by expert testimonies to encourage the predetermined conclusion ${ }^{42}$. This form has been actively adopted in science museums for example, but is seldom encountered in art museums, apart from some activities designed for children. For example, Vincent's travelling case in the Van Gogh museum in Amsterdam offers a range of hands-on activities to help children (and parents) gain some pre-determined knowledge on the artist and his work ${ }^{43}$.

\subsection{Reflection and problems as generator of knowledge}

More and more often, in art museums, visitors are not led towards pre-determined information or solutions, but rather towards a predetermined problem. The disciplinary grounding for such designs is often related to social sciences. For example, the 2012 exhibition at Tate Liverpool 'Art Turning Left: How Values Changed Making 1789-2013' used art as a

43 Van Gogh Museum. Vincent's travelling case. <https:// www.vangoghmuseum.nl/en/whats-on/children-and-families/vincents-travelling-case> (retrieved in April 2016). 
mode of exploration of existing issues, specifically: "to investigate the way that political beliefs had changed how artists produced their work or their attitude towards the ownership, management, and re-design of the means of art production" ${ }^{44}$. Therefore the exhibition was set up not for the visitor to arrive at pre-determined conclusions but to explore a pre-determined problem ${ }^{45}$. The case was chosen as being representative of using art to stimulate reflection on broader political or social issues. This case was analysed through documentation.

Rooms were not organised chronologically or by themes but around questions. Artworks were offered to visitors to stimulate their thinking processes and build hypothesis around the questions posed, without explicitly formulating any answers in the accompanying apparatus (labels, catalogue, etc.). For example, the wall texts were there only to underline unresolved issues. At the centre of the exhibition, the 'Office for Useful Art' provided a bookable public space (physically open to the exhibition space, therefore accessible to all visitors) where works could be relocated to "produce new thinking and discourse around them" ${ }^{46}$. The forms of knowledge produced in such an environment are multiple. Knowledge is here simultaneously person-bound (as the visitor creates their own knowledge) and not (as the public space debates allowed), it is normative (the problem to be explored is set) but open (the resolution to this problem is open). It is internally and externally networked and dynamic: room is left for the 'answers' of the visitors to change and evolve accordingly. The knowledge production works at multiple levels:

- the individual visitor gains cognitive knowledge and skills

The visitor's analytical and critical skills are developed as they are looking to the artworks to answer the questions posed. She/he needs to gather information and interpretations of the work to 'use' the work in building her/his answer to the question. Internal and external networks are therefore developed;

- the individual visitor gains emotional knowledge and skills

Through affective engagement with the works and understanding of the socio-political environments the works were produced in, the visitor develops empathy and a sense of ownership of the works. Identity building blocks are created when the visitor defines more precisely her/his own position and beliefs in regards to that of others;

- the individual visitor gains social

knowledge and skills

The visitor learns about collective interpretation, about mechanisms of communication around the works, about processes of negotiation in meaning-making.

In this case the knowledge producer in the museum is the curator as encoder ${ }^{47}$, as the curator asks the questions and to some measure directs the types of answers through the selection of works. But the curator is also co-producing knowledge with the audience. The art museum then has the potential to be a "learning machine" ${ }^{48}$ where everyone, including the museum staff, learns.

\subsection{Issues related to knowledge produc- tion in the discovery model: discursivity, ownership and display}

The main issues in such cases are that of discursivity and who produces the resolution of the problem ${ }^{49}$, or if there is a resolution at all. Furthermore, the inherently multi-voiced discourse present in this model makes it hard to collect and present all the knowledge created

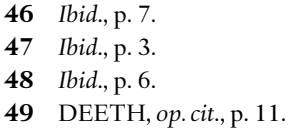

44 MANACORDA, Francesco. "For Whom Do We Write Exhibitions? Towards a Museum as Commons”. Stedelijk Studies. vol. 4, 2016, p. 6.

45 Ibid., p. 7. 
during the exhibition and share it on a broader level especially beyond the exhibition space/ timeframe.

\section{Constructivist model: museums offer and support/visitors do and learn}

In the constructivist model the learner is active in producing knowledge and the learner her/ himself is the measure of that knowledge: it needs to 'make sense' in the reality of the learner rather than adhere to standard truth ${ }^{50}$. This form of exhibition will have, according to Hein, multiple entry points and no specific path, provide a range of active learning opportunities, present multiple viewpoints, enable the visitor to connect museum objects with their own experiences, and allow for experimentation, conjecture, and conclusion drawing ${ }^{51}$. Because it validates different ways to interpret an object, this mode is particularly well suited to art museums.

\subsection{Constructivist model and the building of knowledge in the visitor}

The disciplinary grounding for such practices is varied and ranges from constructivist educational theories to curatorial studies and social sciences. There are, however, very few examples of this approach in art museums. One interesting example is the Van Abbemuseum's 'DIY Archive: Make your own exhibition' (Eindhoven, The Netherlands) ${ }^{52}$. This case was chosen as representative of the potential practices not based on art history as a discipline but rather on curatorial studies. The Van Abbemuseum is well known for its stance on the importance of a museum's social engagement. The case was studied through documentation and direct observation.
In an area of the museum that is part stockroom/archive and part display space, visitors get acquainted with original artworks in a range of media and from diverse periods. Visitors can choose works (again original works), pick them up from the racks, read about them, and curate a temporary display of the works. A member of staff is present to provide the visitors with more information and help them along the way. The visitors can also submit an exhibition proposal that, if selected, is then realised with the museum staff and stays on display for a longer time in the archive room. The forms of knowledge here are cognitive (analytical, critical, networking, and factual), emotional (visitors develop a sense of ownership of the works, their imagination, their creativity, empathy and also layers of identity), as well as psychomotor (handling of artworks, display techniques, etc.).

The work often takes place in a small group cultivating social learning, enhancing for example communication skills.

In this constructivist approach, the visitors are for the most part the knowledge producers. The museum staff only play a very small part in the knowledge production by selecting the artworks that are put in this area and by offering advice during the process. As HooperGreenhill describes, with the constructivist model of museums, "the act of knowing is shaped through a mix of experience, activity, and pleasure, in an environment where both the 'learning' subject and the 'teaching' subject have equal power" ${ }^{53}$. Because the work of the visitors is in an open space means that other visitors can witness and share the knowledge production in a fluid manner. The fact that some exhibitions are showcased for a longer period validates this process of knowledge creation by the visitors with the stamp of the institution. $\mathbf{5 0}$ HEIN, 1998

52 Van Abbemuseum. DIY Archive, Make your own exhibition. <http://vanabbemuseum.nl/en/programme/ detail/?tx_vabdisplay_pi $1 \% 5 B$ ptype $\% 5 \mathrm{D}=32 \&$ tx_vabdisplay_pi1\%5Bproject\%5D=1574> (retrieved in May 2016). 


\subsection{Issues related to knowledge produc- tion in the constructivist model}

While this model produces a wide range of knowledge in the visitor, the main issues are related to:

- artwork conservation as the original artworks are manipulated by the visitors;

- issues of authority and authorship: who is responsible for the content of the exhibitions?;

- issues of expertise: the expertise of the museum staff is changing from content to process, from factual knowledge to the ability to apply this knowledge in a given context and help the generating of new knowledge.

\section{Conclusion: going further, hybrid models and 'ignorant museums'}

This article has attempted to show the diversity of forms of knowledge production in art museums and to discuss, within Hein's framework, who is producing what kind of knowledge and how it is communicated. We have looked at a few limited examples to illustrate the different models: didactic/ expository, stimulus-response, discovery and constructivism. The richness of potential knowledge production in the art museum and how each model seems to suit a specific type of knowledge production (with some overlaps of course) is striking. The didactic/ expository model promotes essentially a range of cognitive learning; the stimulus-response model promotes mostly interpretation skills and emotional knowledge (personal and social); the discovery model facilitates the development of critical skills as well as a range of cognitive, emotional and social knowledge; the constructivist model places it emphasis on the self-generative aspect of knowledge production as well as serve some cognitive, emotional and psychomotor knowledge production. No model is complete and the choice between different exhibition strategies depends very much on the disciplinary grounding of the museums, their aspiration in terms of knowledge production for the visitors as well as their willingness to let go of some of their authority.

However, it is clear that, as the museum mission evolves and centres more and more on the visitor's knowledge production, the didactic/ expository model based on art history as a discipline runs the risk of fast becoming obsolete. More constructivist practices in the museum space certainly have a role to play in this renewal of the art museum. As HooperGreenhill remarks, "knowing and knowledge have become three-dimensional, all-involving, and all-encompassing. The main themes of knowledge are people, their histories, their lives, and their relationships" ${ }^{54}$. In that regard, art museums should be prompted to open up and merge different approaches, to dare to experiment with different models and to embrace the diversity implied in knowledge production related to art collections. But how to go further? How to optimise and combine different types of knowledge production? How to adapt to different types of learners?

\subsection{Hybrid models}

As we mentioned, no single model covers the whole range of knowledge production. It therefore seems logical to consider that a varied approach will lead to a richer knowledge production process. Hybrid models that encompass several approaches within one space can help reach this goal. The Van Abbemuseum that we mentioned in the constructivist model tries to adopt a variety of approaches in the museum as a whole. 'The collection now' exhibition aims to "tell stories of aesthetics, ethics and politics over the last 100 year" ${ }^{35}$. While its focus is not solely art historical, the

55 Van Abbemuseum. The Collection Now, <https:/| vanabbemuseum.nl/en/programme/programme/the-collection-now/> (Retrieved in December 2016). 
intent is didactic/expository. Its location, intertwined with other thematic or experiential exhibitions as well as with the constructivist 'DIY Archive' offers a range of alternative for knowledge production in the museum.

However, it may be more efficient to combine approaches within a single exhibition to reinforce the self-generating potential of the knowledge production process. It is important to note that it is the diversity of approaches that is crucial to knowledge production in the art museum as it attempts to accommodate the needs of diverse publics, types of learners, communities and forms of art.

\subsection{The 'ignorant art museum'56}

The 'ignorant museum' is based on Jacques Rancière's view on education and the idea of the 'ignorant schoolmaster'57. Yuha Jung proposed this idea in her text "The ignorant museum: transforming the elitist museum into an inclusive learning place." 58 She focused on merging Paulo Freire's pedagogy of the oppressed and Rancière's emancipatory education principles. The "ignorant museum" is a fruitful principle and we do not see that concept as solely a means to reduce elitism in museum (even though this is highly desirable) but also as a way to merge different approaches to museum knowledge creation.

In his text Rancière attacks the 'explanation' as one of the downfall of the education system. He explains that the explanation reduces and oversimplifies knowledge and limits the knowledge creation process. Rancière argues that learning through experience, chance, failure and self-correction emancipates learners by forcing them to use and develop their own knowledge. One can ask how different it is from the constructivist approach. Indeed, the intervention of the museum as an institution is minimal

56 This concept deserves further study and will be the central topic of an upcoming article (autumn 2017).

57 RANCIÈRE, Jacques. Le Maître ignorant. Paris: Fayard, 1987.

58 JUNG, Yuha. 'The ignorant Museum: transforming the elitist museum into an inclusive learning place'. In. ABERY Nicole (ed). The new museum community: Audiences, challenges, benefits. Edinburgh: Museums Etc, 2010, p. 272-291. but still present in both occurrences. The main difference is in the institutional commitment to an on-going learning process and in the clarity of the learning goals. To Rancière, the core of learning is in the will to learn and motivation of the learner (which the schoolmaster/museum can support). One of the main dangers of such a model in art museums is the negation of the museum as a centre of expertise in the traditional sense. Just as for the constructivist model, the ignorant art museum staff, need to assert a new type of expertise to do with the ability to apply knowledge in a given context and help generate new knowledge.

To conclude we should note that further studies that take into account visitors' expectations of art museum visits (openness of interpretation, type of authorial voice of the institution, etc.) should also be added to complete the picture of knowledge production in the art museum. It is also worth noting that while the different types of museum mediation were at the heart of this article, the type of art presented by the museum also has an impact on the kind of knowledge created. Immersive installations such as those of Yayoi Kusama's retrospective at the Louisiana Museum (Humlebæk, Denmark $)^{59}$ have a very different impact on the visitor's knowledge production than discursive art such as that presented in the exhibition 'Guerrilla Girls 1985-Today'60. Different mediation approaches may suit better different types of artworks.

We have shown in this article that knowledge production in art museums is multifarious and that specific exhibition strategies promote certain types of knowledge production. We have concluded that hybrid approaches could be fruitful in art museums as well as closer collaboration between disciplines and educators, curators, conservators, and the public. Finally

59 Louisiana Museum of Modern Art. Yayoi Kusama. <https://en.louisiana.dk/exhibition/yayoi-kusama> (retrieved in December 2015).

60 Van Abbemuseum. Guerilla Girls 1985-Today. <http:// vanabbemuseum.nl/en/programme/detail/?tx_vabdisplay_pi $\% 5$ Bptype $\% 5 \mathrm{D}=18 \&$ tx_vabdisplay_pi1\%5Bprojec$\mathrm{t} \% 5 \mathrm{D}=2290>($ retrieved in June 2016). 
the idea of an 'ignorant art museum' was

briefly introduced along with its potential for

knowledge creation. 


\section{Les nombreux visages de la production de connaissances dans les musées d'art : une exploration des stratégies d'exposition}

Les dernières décennies ont vu la production de savoirs devenir un des objectifs centraux des musées. Ceci est partiellement dû au développement de nouvelles formes de médiation centrées sur les visiteurs, telles que la muséologie, les approches muséales constructivistes et les pratiques participatives. Cette réalité pose cependant des défis particuliers aux musées d'art. Parce que de façon globale, les services d'éducation des musées d'art sont graduellement renommés " services aux publics ", ou "services éducatifs ", et parce que les musées se considèrent euxmêmes des "lieux d'éducation informelle ", il importe de se questionner sur la nature de la production artistique, sur ce qui la constitue et ce qu'elle signifie.

Afin d'explorer les nombreuses facettes de l'apprentissage dans les musées d'art, cet article met en oeuvre la théorie de George Hein tirée de son ouvrage séminal Learning in the Museum. Dans ce texte, Hein propose un cadre particulièrement utile pour réfléchir à la position des musées d'art en matière de production de connaissances et de stratégie d'exposition. Les quatre modèles qu'il élabore - didactique/expositif, découverte, stimulus-réponse et constructivisme - forment le cadre théorique, la structure de base de notre analyse qui vise à comprendre en quoi consiste la production de connaissances dans les musées d'art, et qu'elle est la nature de cette production. Est-ce que la production de connaissances dans les musées d'art concerne essentiellement la création de nouvelles expositions, l'expérimentation de nouveaux mediums, la production de nouveaux liens, la production de connaissances d'ordre esthétique, émotionnel et empathique, la reconnaissance des modèles, l'acquisition de notions d'histoire de l'art, ou l'acquisition de compétences analytiques et critiques? Nous nous interrogerons aussi sur l'identité des producteurs de savoir parmi chacun des modèles muséaux: les artistes, les conservateurs, l'équipe affecté aux services éducatifs ou le public? Nous chercherons enfin à comprendre comment la production de savoirs est diffusée dans les musées d'art. Tiré du cadre théorique d'Hein, chaque modèle soit, la didactique/expositoire, la découverte, le stimulus-réponse et le constructivisme est mis en contexte à même un cas d'étude afin que l'analyse soit la plus claire possible. À la suite de cette exploration sur la diversité de la production de savoirs associée à des stratégies d'exposition spécifiques, nous évaluons les possibilités de dépassement des modèles standards de Hein, et explorons ce que la production de connaissances issue de modèles alternatifs et hybrides pourrait représenter.

Cet article démontre que la diversité des approches est cruciale pour la production de connaissances dans le musée d'art, car il s'agit de moyens qui permettent de répondre aux besoins de divers publics, de divers types d'apprenants, de communautés et de formes d'art. Cette étude souligne l'importance de la conception des expositions et maintenant plus que jamais, de la primordialité du travail collaboratif et interdisciplinaire entre éducateurs, conservateurs, curateurs, et public. 